Assessment in Social Work 
Also by Judith Milner

Exclusion from School: Interprofessional Issues for Policy and Practice

Child Sexual Abuse: A Guide for Teachers

Also by Patrick O'Byrne

Applying Family Therapy (with H.C. Masson) 


\title{
Assessment in Social Work
}

\author{
Judith Milner
}

and

\author{
Patrick O’Byrne
}

Consultant editor: Jo Campling

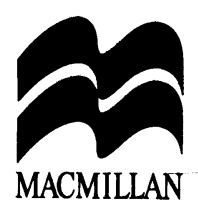




\section{2}

C Judith Milner and Patrick O'Byrne 1998

All rights reserved. No reproduction, copy or transmission of this publication may be made without written permission.

No paragraph of this publication may be reproduced, copied or transmitted save with written permission or in accordance with the provisions of the Copyright, Designs and Patents Act 1988, or under the terms of any licence permitting limited copying issued by the Copyright Licensing Agency, 90 Tottenham Court Road, London W1P 9HE.

Any person who does any unauthorised act in relation to this publication may be liable to criminal prosecution and civil claims for damages.

The authors have asserted their rights to be identified as the authors of this work in accordance with the Copyright, Designs and Patents Act 1988.

First published 1998 by MACMILLAN PRESS LTD

Houndmills, Basingstoke, Hampshire RG21 6XS and London Companies and representatives throughout the world

ISBN 978-0-333-65919-9

DOI 10.1007/978-1-349-14054-1

A catalogue record for this book is available from the British Library.

This book is printed on paper suitable for recycling and made from fully managed and sustained forest sources.

$\begin{array}{rrrrrrrrrr}10 & 9 & 8 & 7 & 6 & 5 & 4 & 3 & 2 & 1 \\ 07 & 06 & 05 & 04 & 03 & 02 & 01 & 00 & 99 & 98\end{array}$

Editing and origination by Aardvark Editorial, Suffolk 
To Huddersfield University Diploma in Social Work students, past and present, whose contributions in lectures and seminars helped us to develop our ideas about assessment. 


\section{Contents}

List of Tables and Figures viii

Acknowledgements ix

1 Introduction 1

2 From Traditional Practice to Current Legislation 7

3 Outcome Evaluation and the Assessment Process 26

4 Selecting a Map 44

5 The Weather Map: Anti-oppressive Practice 60

6 A Map of the World: the Systems Approach 79

7 A Map of the Ocean: Psychodynamic Approaches 96

8 An Ordnance Survey Map: Behavioural Approaches 112

9 The Handy Tourist Map: Task-centred Approaches 130

10 The Navigator's Map: Solution-focused Approaches 146

11 Making and Finalising the Judgment 164

12 Conclusion 183

References 187

Index 201 


\section{List of Tables and Figures}

Tables

$2.1 \quad$ Principles underpinning recent legislation 22

4.1 Social science theory 50

$\begin{array}{lll}7.1 & \text { Stages of human development } & 108\end{array}$

\section{Figures}

3.1 A data collection grid 38

6.1 Pincus and Minahan's four systems 81

6.2 Systems - example a $\quad 88$

6.3 Systems - example b $\quad 89$

7.1 . Mind and world 97

7.2 Parent-Adult-Child 105

7.3 An ego gram 106

8.1 Reinforcement and punishment 116

8.2 Record of behaviour 117

$\begin{array}{ll}8.3 \text { Behavioural baseline } & 120\end{array}$

8.4 Response record 125

9.1 Want Sheet 133

9.2 Problem scale 135

9.3 Mr and Mrs K's completed problem scale 142

10.1 Solution-focused work - session 1

10.2 Solution-focused work - session 2 


\section{Acknowledgements}

There are many people who deserve our thanks for their help in the writing of this book. Not least are our colleagues, Pat Bastian, Eric Blyth, Christine Horrocks and Wendy Marshall, for their helpful comments on early drafts; Maxine Hamilton for her case example; Sue Hanson who translated our feeble efforts at word processing into a readable text with her usual cheerful efficiency; and Jo Campling for her support and guidance. We also wish to acknowledge the contribution of colleagues more generally. Our efforts have been greatly facilitated by the fact that we work in a stimulating social work department at the University of Huddersfield, which is well supported by agency partners and management. This has meant not only that we have benefited from a healthy exchange of ideas, but also that we have been well supported in our efforts in terms of time, advice and encouragement. We thank you all.

Last, but not least, we are grateful to Mary O'Byrne who tolerated Patrick's strange working hours during the preparation of the text with unfailing good humour, and to Rosie who bore with Judith's hours with stoic patience. 